\title{
ASSESSMENT OF ANTIOXIDANT POTENTIAL AND ANTIGENOTOXICITY ANALYSIS THROUGH HYDROGEN PEROXIDE-INDUCED OXIDATIVE STRESS IN TERMINALIA PANICULATA ROTH
}

\author{
ASWATHI P ${ }^{1 *}$, JOHN ERNEST THOPPIL ${ }^{2}$ \\ Department of Botany, University of Calicut, Cell and Molecular Biology Division, Malappuram, Kerala, India. \\ Email: aswathipokkadath@gmail.com
}

Received: 02 May 2020, Revised and Accepted: 12 June 2020

\section{ABSTRACT}

Objective: The present study is mainly focused on the antigenotoxicity and antioxidant potential of the fruit extract of an important dye yielding plant Terminalia paniculata Roth.

Methods: Genoprotective activity of the fruit extract was studied by Allium cepa root tip assay. Three modes of treatment were used to perform the antigenotoxicity, that is, pre-treatment, post-treatment, and simultaneous treatment. For the study of antioxidant potential, four different assays were performed.

Results: Antigenotoxicity studies revealed the protective role of the extract in chromosomal aberrations induced by $2 \%$ hydrogen peroxide $\left(\mathrm{H}_{2} \mathrm{O}_{2}\right)$ on $A$. cepa root tip meristem. The fruit extract showed a significant modulatory effect by means of an inhibition percentage and also it showed a characteristic reversing of chromosomal aberrations induced by $\mathrm{H}_{2} \mathrm{O}_{2}$. While in the case of antioxidant activity, the plant extract showed an appreciable antioxidant potential. Four different assays were used to determine the antioxidant potential of T. paniculata. Of these 2,2-diphenyl-1-picryl-hydrazylhydrate radical scavenging activity revealed almost equal effect to that of the standard.

Conclusions: In the present investigation, it has been found that the important dye yielding plant T. paniculata has a significant role in various commercial industries such as food, cosmetics, clothes, and pharmaceutics due to its efficient protective role.

Keywords: Genotoxicity, Oxidative stress, Terminalia paniculata, Antioxidant potential.

(C) 2020 The Authors. Published by Innovare Academic Sciences Pvt Ltd. This is an open access article under the CC BY license (http://creativecommons. org/licenses/by/4. 0/) DOI: http://dx.doi.org/10.22159/ajpcr.2020.v13i8.38123

\section{INTRODUCTION}

Natural products have been of immense importance to humans from ancient times. The main sources among them are the plants, without them the mankind is worthless. Terminalia paniculata, an arborescent tree which seems to be used as timber and shelter by our ancestors, is gaining attention toward pharmaceutical products nowadays.

Natural dyes have a massive utility in textile, drug, and cosmetic industries as a coloring agent. It is widely used in foodstuff coloring, also due to their negligible toxicity. Hence instead of synthetic colorants, natural ones can promote a perfect and healthy life. Earlier studies on the induction of giant cells [1] and apoptotic activity and DNA damage as well as metabolic inactivation [2] had proved the cytotoxicity of some common synthetic food dyes. T. paniculata is an important dye yielding plant belonging to Combretaceae. Its fruits are used as the major source of the dye.

Biological systems possess destructive free radicals as a result of metabolic processes. Antioxidant activity can determine the ability of a drug to scavenge these free radicals. Oxidation is a significant process in living organisms for the indispensable performing of catabolism. However, oxygen centered free radicals and several reactive oxygen species were produced inside the body may cause severe diseases such as atherosclerosis, diabetes, cancer, and cirrhosis [3]. Environmental pollutants such as automobile exhaust, radiation, air pollution, cigarette smoke, and pesticides can play a key role to generate free radicals [4]. Normally, there is a balance between the quantity of free radicals generated in the body and the antioxidant defense systems, which protect the body from the deleterious effects by scavenging these destructive free radicals [5]

Hydrogen peroxide $\left(\mathrm{H}_{2} \mathrm{O}_{2}\right)$ is one of the severe mutagens and it has a great effect on the DNA directly, causing DNA strand breakage and base modification. It can modulate the transcription and suppress genomic repair pathways [6] $\mathrm{H}_{2} \mathrm{O}_{2}$ has the ability to generate reactive oxygen species on cells and it may lead to oxidative-stress-mediated cytotoxicity by various chemical reactions. For this reason, it may cause severe oxidative damage to membrane lipids, DNA molecules, and proteins $[7,8]$.

Dyes obtained from the natural products have great significance both commercially as well as aesthetically. Hence, the main objective of the present study was to evaluate the antigenotoxicity and antioxidant activities of the methanolic extract of the fruits of $T$. paniculata.

\section{METHODS}

\section{Antigenotoxicity}

Three different methods are used to determine the antigenotoxicity of the fruit extract of T. paniculata, that is, pre-treatment, posttreatment, and simultaneous treatment [9]. In pre-treatment, at first, the roots were treated with different concentrations $(0.1,0.05$, 0.01 , and $0.005 \%$ ) of the fruit extract for $24 \mathrm{~h}$ followed by $\mathrm{H}_{2} \mathrm{O}_{2}$ $(2 \%)$ treatment for $1 \mathrm{~h}$. In post-treatment, roots were first treated in $2 \% \mathrm{H}_{2} \mathrm{O}_{2}(1 \mathrm{~h})$ and were followed by $24 \mathrm{~h}$ treatment with different concentrations of the fruit extract. In the case of simultaneous treatment, the roots were treated simultaneously with $\mathrm{H}_{2} \mathrm{O}_{2}(2 \%)$ and fruit extract of different concentrations for $1 \mathrm{~h} . \mathrm{H}_{2} \mathrm{O}_{2}$ (2\%) and distilled water were taken as positive and negative control, respectively. Then, the treated root tips were washed thoroughly with distilled water and immediately fixed in modified Carnoy's fluid (1 acetic acid:2 alcohol) for $1 \mathrm{~h}$. After washing in distilled water, it was hydrolyzed in $1 \mathrm{~N} \mathrm{HCl}$ for 5-10 min to separate the cells during squashing and stained with $2 \%$ acetocarmine for $4 \mathrm{~h}$. After staining, the root tips were destained with $45 \%$ acetic acid, squashed, and mounted on clean micro slides. 
Mounted slides were observed for aberrations under a microscope (Leica DM 2000 LED) and photographs were taken.

$$
\text { Abnormality percentage }=\frac{\text { Number of abnormal cells }}{\text { Total number of cells }} \times 100
$$

$$
\text { Inhibitory activity }(\%)=\frac{A-B}{A-C} \times 100
$$

Where, $\mathrm{A}=$ number of aberrant cells induced by positive control, $\mathrm{B}=$ number of aberrant cells induced by different modes of treatment, and $\mathrm{C}=$ number of aberrant cells induced by negative control.

\section{Statistical analyses}

Statistical analyses were carried out using SPSS version 10. Data obtained were then subjected to Duncan's multiple range test and one-way analysis of variance to authenticate the variability of the data and accuracy of results. Mean \pm SE and differences between the corresponding controls and various treatments of the results are expressed and were considered statistically significant at $\mathrm{p}<0.05$. The linear relationship between dose and the effect of aqueous extract in terms of inhibition percentage was obtained by simple regression and correlation analysis.

\section{Antioxidant activity}

Four different assays were used to detect the antioxidant activity of the methanolic extract of the fruit extract of $T$. paniculata, that is, 2,2-diphenyl-1-picryl-hydrazyl-hydrate (DPPH) radical scavenging activity, hydroxyl radical scavenging activity, nitric oxide scavenging activity, and superoxide free radical scavenging activity.

\section{DPPH radical scavenging activity}

The radical scavenging activity of different extracts was determined using DPPH assay according to Chang et al. [10]. The decrease in the absorption of the DPPH solution after the addition of an antioxidant was measured at $517 \mathrm{~nm}$. Ascorbic acid (10 $\mathrm{mg} / \mathrm{ml}$ dimethyl sulfoxide [DMSO]) was used as a reference.

Different concentrations of sample such as $12.5 \mu \mathrm{g} / \mathrm{mL}-200 \mu \mathrm{g} / \mathrm{mL}$ from a stock concentration $(10 \mathrm{mg} / \mathrm{mL}$ ) were made up to a final volume of $20 \mu \mathrm{l}$ with DMSO and $1.48 \mathrm{ml}$ DPPH (0.1 mM) solution was added. A control without the test compound, but an equivalent amount of distilled water was taken. The reaction mixture was incubated in dark at room temperature for $20 \mathrm{~min}$. The absorbance of the mixture was read at $517 \mathrm{~nm} .3 \mathrm{ml}$ of DPPH was taken as control.

\section{Hydroxyl radical scavenging activity}

Different concentration of sample such as $125-2000 \mu \mathrm{g} / \mathrm{mL}$ from a stock solution $(10 \mathrm{mg} / \mathrm{mL})$ was mixed with $500 \mu$ l reaction mixture (2 deoxy, 2 ribose $(2.8 \mathrm{mM}), \mathrm{FeCl}_{3}(100 \mu \mathrm{m})$, ethylenediaminetetraacetic acid (EDTA) $(100 \mu \mathrm{m}), \mathrm{H}_{2} \mathrm{O}_{2}(1.0 \mathrm{mM})$, and ascorbic acid $(100 \mu \mathrm{m})$ in $\mathrm{KH}_{2} \mathrm{PO}_{4}-\mathrm{KOH}$ buffer $(20 \mathrm{mM}$ pH 7.4) was made up to a final volume of $1 \mathrm{ml}$. A control without the test compound, but an equivalent amount of distilled water was taken. After incubation for $1 \mathrm{~h}$ at $37^{\circ} \mathrm{C}$, add $1 \mathrm{ml}$ of $2.8 \%$ trichloroacetic acid, then $1 \mathrm{ml} 1 \%$ aqueous thiobarbituric acid was added, and the mixture was incubated at $90^{\circ} \mathrm{C}$ for $15 \mathrm{~min}$ to produce the color. After cooling, the absorbance was read at $532 \mathrm{~nm}$ [11].

\section{Nitric oxide scavenging activity}

Sodium nitroprusside (5 mmol/L) was mixed with different concentrations of sample such as $125 \mu \mathrm{g} / \mathrm{mL}-2000 \mu \mathrm{g} / \mathrm{mL}$ and incubated at $25^{\circ} \mathrm{C}$ for $30 \mathrm{~min}$. A control without the test compound, but an equivalent amount of distilled water was taken. After $30 \mathrm{~min}$, $1.5 \mathrm{~mL}$ of the incubated solution was removed and diluted with $1.5 \mathrm{~mL}$ of Griess reagent (1\% sulfanilamide, $2 \%$ phosphoric acid, and $0.1 \%$ N-1-naphthyl ethylene diamine dihydrochloride). The absorbance of the chromophore formed during diazotization of the nitrate with sulfanilamide and subsequent coupling with $\mathrm{N}-1$ naphthyl ethylenediamine dihydrochloride was measured at $546 \mathrm{~nm}$ [12].

\section{Superoxide free radical scavenging activity}

Different concentration of sample from 125 to $2000 \mu \mathrm{g} / \mathrm{ml}, 0.05 \mathrm{ml}$ of riboflavin solution $(0.12 \mathrm{mM}), 0.2 \mathrm{ml}$ of EDTA solution $(0.1 \mathrm{M})$, and $0.1 \mathrm{ml}$ nitroblue tetrazolium solution $(1.5 \mathrm{mM})$ was mixed in test tube and reaction mixture was diluted up to $2.64 \mathrm{ml}$ with phosphate buffer $(0.067 \mathrm{M})$. A control without the test compound, but an equivalent amount of distilled water was taken. The absorbance was read at 560 $\mathrm{nm}$ after illumination for $5 \mathrm{~min}$ incubation in fluorescent light and also measured after $30 \mathrm{~min}$ at $560 \mathrm{~nm} \mathrm{[13].}$

In all four different antioxidant assays, the percentage of inhibition was calculated using the following formula.

$$
\text { Percentage of inhibition }=\frac{\text { control }- \text { test }}{\text { control }} \times 100
$$

\section{RESULTS}

\section{Antigenotoxicity}

The present is study mainly focused on the protective effect of $T$. paniculata fruit extract on $\mathrm{H}_{2} \mathrm{O}_{2}$-induced oxidative damage. $\mathrm{H}_{2} \mathrm{O}_{2}$ is an important exogenous oxidant and it can induce oxidative stress on the Allium cepa root tip cells. Furthermore, it may cause a wide range of aberrations. However, the present study investigated the potential activity of extract to modulate the intensity of aberrations due to the exogenous oxidant. Oxygen centered free radicals and several reactive oxygen species produced inside the body may cause severe diseases, so the studies regarding the oxidative damages and its cure are very much informative and effective. The modulatory activity of T. paniculata on A. cepa treated with $\mathrm{H}_{2} \mathrm{O}_{2}$ was clearly mentioned in Table 1 . The result revealed that there is a dose-dependent decrease of chromosomal aberrations. The $\mathrm{H}_{2} \mathrm{O}_{2}$-treated root tips showed a variety of chromosomal aberrations, particularly nuclear lesions. Cytoplasmic shrinkage, nuclear disintegration, bizarre nucleus, etc., were also found. The $\mathrm{H}_{2} \mathrm{O}_{2}$ root tips treated when supplemented with plant extract can cause a drastic change back to the normalcy (Fig. 1). It meant that the plant extract has an effective correlation on the inhibitory activity at different levels of concentrations. All three treatments (pre, post, and simultaneous) showed an almost equal effect on the various concentrations. In pre-treatment, the percentage

Table 1: Modulatory activity of T. paniculata on A. cepa root tip meristem treated with $2 \% \mathrm{H}_{2} \mathrm{O}_{2}$ Means with the same superscript letter do not differ statistically at the level of 0.05 (p<0.05; DMRT test)

\begin{tabular}{lll}
\hline Concentration & $\begin{array}{l}\text { Chromosomal abnormal } \\
\text { percentage } \pm \text { SE }\end{array}$ & $\begin{array}{l}\text { Percentage of } \\
\text { inhibition } \pm \text { SE }\end{array}$ \\
\hline $\begin{array}{l}\text { Negative control } \\
\text { Positive control }\end{array}$ & $\begin{array}{l}5.69 \pm 0.05^{\mathrm{a}, \mathrm{b}} \\
\text { Pre-treatment } \%)\end{array}$ & $0000^{\mathrm{a}}$ \\
0.005 & $60.0000 \pm 3.65923^{\mathrm{a}}$ & $0000^{\mathrm{a}}$ \\
0.01 & $54.1333 \pm 2.17128^{\mathrm{a}}$ & $74.5 \pm 0.5^{\mathrm{a}}$ \\
0.05 & $52.43333 \pm 1.08985^{\mathrm{b}}$ & $75.5 \pm 0.32^{\mathrm{b}}$ \\
0.1 & $46.6333 \pm 1.44491^{\mathrm{b}}$ & $78.5 \pm 0.29^{\mathrm{a}}$ \\
Post-treatment & & \\
0.005 & $61.7000 \pm 1.37961^{\mathrm{a}}$ & $70.7 \pm 0.46^{\mathrm{a}}$ \\
0.01 & $57.2000 \pm 1.50997^{\mathrm{a}}$ & $75.4 \pm 0.72^{\mathrm{a}}$ \\
0.05 & $52.1667 \pm 1.67564^{\mathrm{b}}$ & $77.7 \pm 0.45^{\mathrm{b}}$ \\
0.1 & $47.3000 \pm 1.05987^{\mathrm{a}, \mathrm{b}}$ & $78.3 \pm 0.26^{\mathrm{d}}$ \\
Simultaneous treatment & \\
0.005 & $64.6667 \pm 1.07445^{\mathrm{a}}$ & $61.23 \pm 0.14^{\mathrm{a}}$ \\
0.01 & $59.6333 \pm 1.63333^{\mathrm{a}}$ & $72.73 \pm 0.24^{\mathrm{b}}$ \\
0.05 & $54.9333 \pm 1.98522^{\mathrm{a}}$ & $76.5 \pm 0.25^{\mathrm{c}}$ \\
0.1 & $48.4333 \pm 0.88380^{\mathrm{a}, \mathrm{b}}$ & $79.2 \pm 0.8^{\mathrm{b}}$ \\
\hline
\end{tabular}

T. paniculata: Terminalia paniculata, A. cepa: Allium cepa, $\mathrm{H}_{2} \mathrm{O}_{2}$ : Hydrogen peroxide, DMRT: Duncan's multiple range test 
of inhibition ranged from $74 \%$ to $79 \%$, similarly in post and simultaneous treatments, it was from $70 \%$ to $79 \%$ and $61 \%$ to $80 \%$, respectively. The linear relationship between percentage inhibition and concentrations $(0.005 \%, 0.01 \%, 0.05 \%$, and $0.1 \%)$ of aqueous extract of T. paniculata was obtained by regression and correlation analyses (Fig. 2).

\section{Antioxidant activity}

Various metabolic actions in the body will generate multiple destructive free radicals. The present study revealed that the fruit extract of $T$. paniculata has an appreciable ability to scavenge these free radicals. All the four different antioxidant assays gave significant results about the scavenging effect of the plant. Dose-dependent scavenging activity was observed in all assays. In DPPH radical scavenging assay, the $\mathrm{IC}_{50}$ was obtained as $23.068 \mu \mathrm{g} / \mathrm{mL}$, which was almost similar to that of ascorbic acid $(20.399 \mu \mathrm{g} / \mathrm{mL})$. In the case of hydroxyl radical scavenging activity, the maximum effect was found at the highest concentration, that is, $63.57 \pm 0.92$. Its $\mathrm{IC}_{50}$ value was $419.64 \mu \mathrm{g} / \mathrm{mL}$. Here, gallic acid was used as the standard with $\mathrm{IC}_{50}$ value, $199.23 \mu \mathrm{g} / \mathrm{mL}$. For nitric oxide scavenging assay, the concentrations tested were 150, 250, 500, 1000 , and $2000 \mu \mathrm{g} / \mathrm{mL}$. Here also dose-dependent scavenging activity was observed. A similar condition was noted in the superoxide free radical scavenging activity. That means T. paniculata showed significant antioxidant potential.

\section{DPPH free radical scavenging assay}

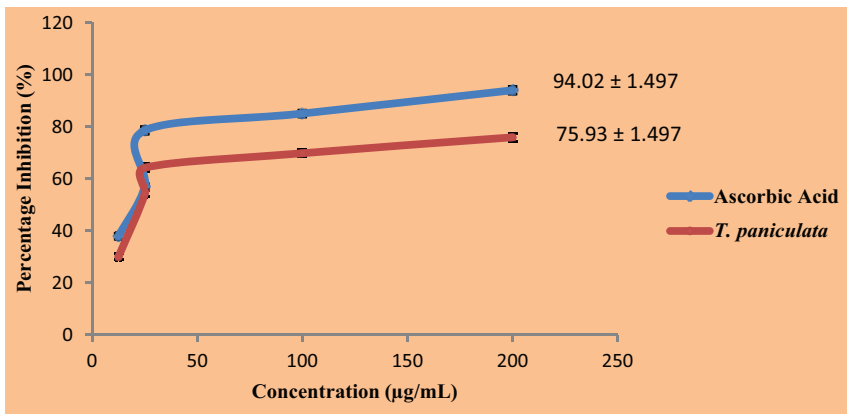

Hydroxyl radical scavenging activity

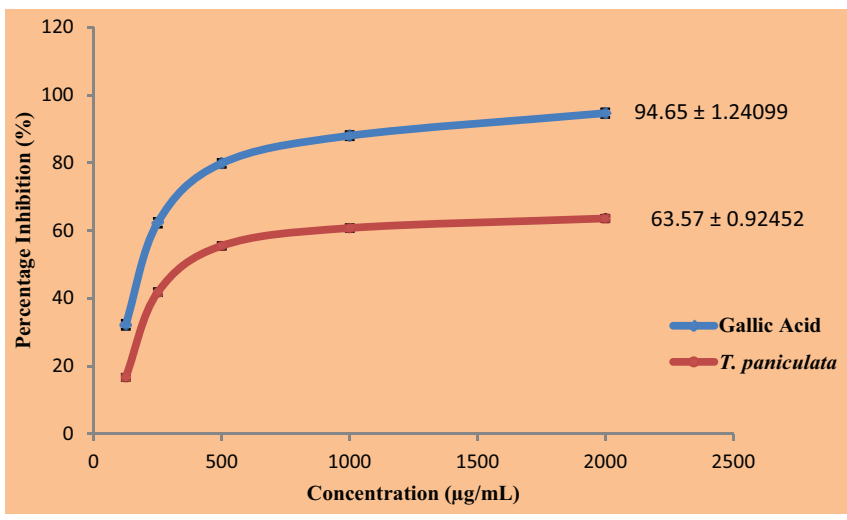

Nitric oxide scavenging activity

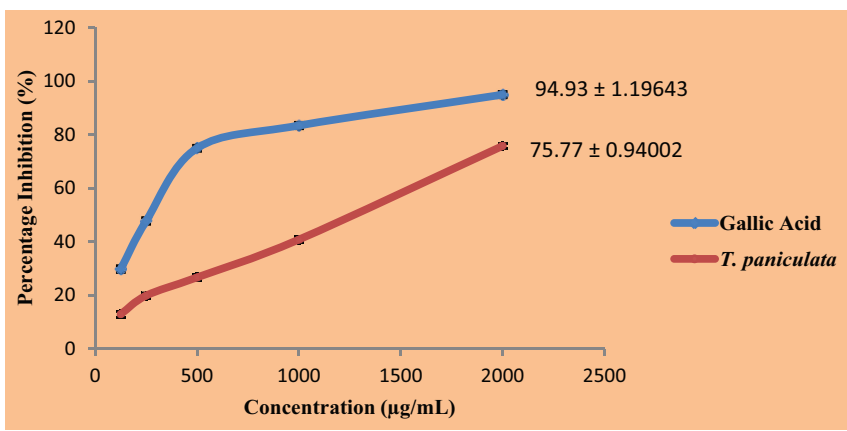

Superoxide free radical scavenging activity
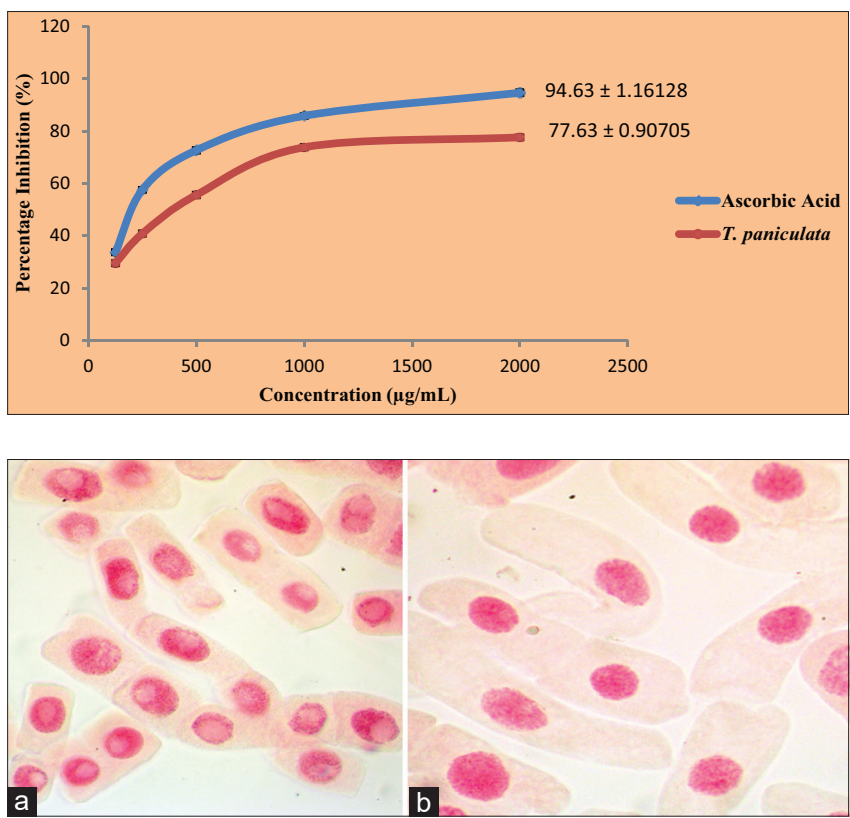

Fig. 1: (a) Nuclear lesions induced after treatment with $2 \%$ hydrogen peroxide; (b) modulatory action of Terminalia paniculata extract showing return of cells to normalcy after treatment

\section{DISCUSSION}

$\mathrm{H}_{2} \mathrm{O}_{2}$ was already proved that it is an important exogenous oxidant and makes damages to the cells and tissues. The addition of $\mathrm{H}_{2} \mathrm{O}_{2}$ may cause cancer associated to several inflammation risks [14]. Hence, the modulatory action of the plant extract was screened using $\mathrm{H}_{2} \mathrm{O}_{2}$. The results regarding the percentage of inhibition of T. paniculata can be explained that in the qualitative phytochemical analysis when the phenolic content was tested, it revealed an intense color. Moreover, previous studies $[15,16]$ have revealed that the combined action between the activity of phenolic contents and $\mathrm{H}_{2} \mathrm{O}_{2}$ can scavenge ROS generated by $\mathrm{H}_{2} \mathrm{O}_{2}$. The present study revealed that $T$. paniculata fruit extract has an appreciable antioxidant potential associated with antigenotoxicity.

DNA is a biologically important target for reactive oxygen species, free oxygen is relatively unreactive with DNA. $\mathrm{H}_{2} \mathrm{O}_{2}$ and free oxygen have a major role to participate in the production of singlet oxygen and peroxynitrite. The production of these species may be synchronized with reactions involving iron, and under some other conditions, they might be important contributors to $\mathrm{H}_{2} \mathrm{O}_{2}$ toxicity.

The protective effects could be co-related to cellular adaptive responses. This may be due to the ability of flavonoids to scavenge free radicals and induce the expression of genes coding for the antioxidant enzymes [17]. The antioxidant modulatory effect of the plant extract might be due to the presence of phenolic compounds [16]. In some flavonoids, the phytochelatins chelate the exogenous compounds and detoxify the reactive oxygen species [18]. Hence, the present results gave an idea about the genoprotective effect of the fruit extract of T. paniculata which may be due to the combined or individual actions of the phytochemicals present in it.

Four different assays were used to test the antioxidant potential of the fruit extract of the plant, T. paniculata. Widely used methods can generate free radical species but which are neutralized by antioxidant compounds [19]. $\mathrm{IC}_{50}$ values revealed that the concentration of extracts of Terminalia arjuna caused a 50\% neutralization of DPPH radicals [20]. From the present study the IC50 value of Terminalia paniculata was recorded as $23.068 \mu \mathrm{g} /$ $\mathrm{ml}$ whereas the IC50 value for ascorbic acid (standard) was recorded as 


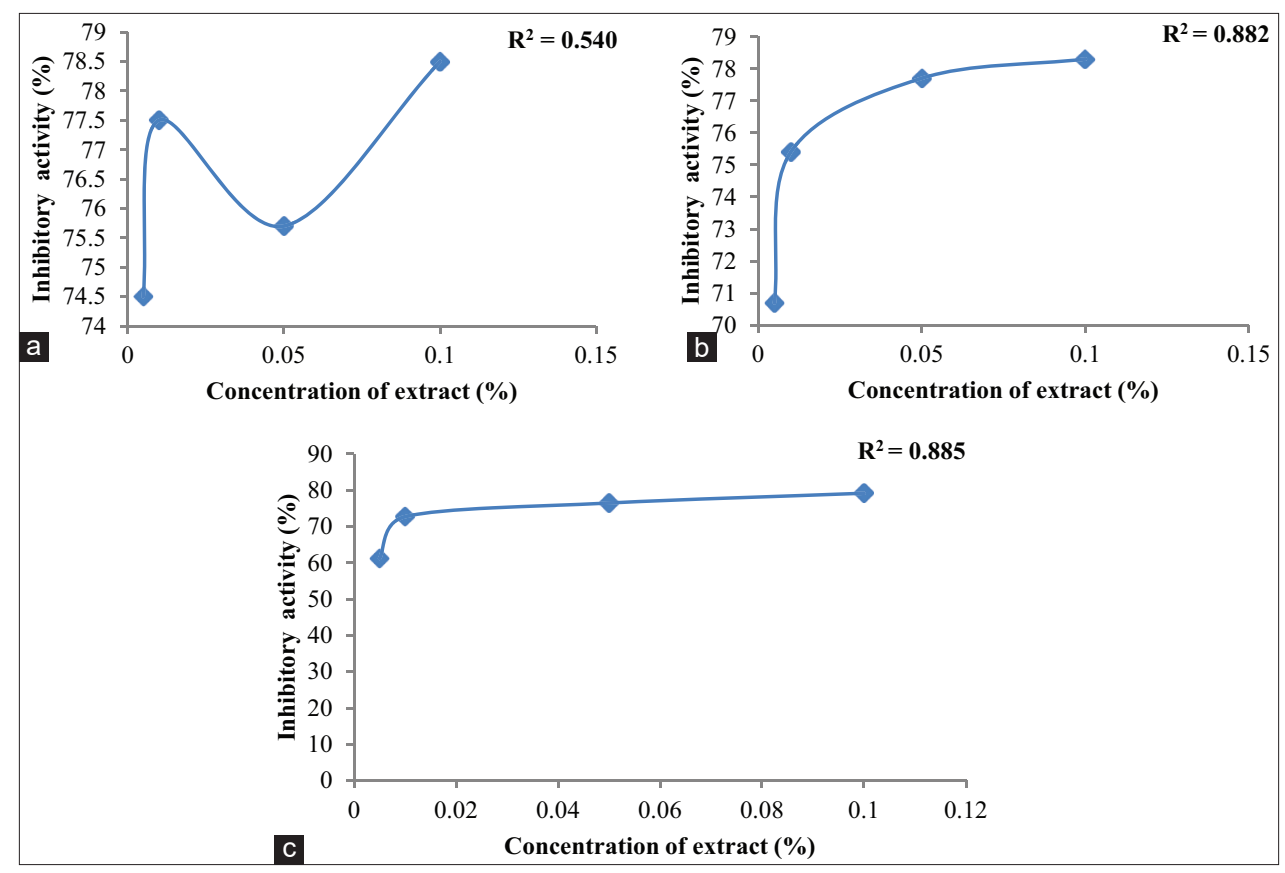

Fig. 2: Relationship between different concentrations of aqueous extract of Terminalia paniculata and percentage inhibition induced by hydrogen peroxide (2\%) in Allium cepa root. (a) Pre-treatment; (b) post-treatment; (c) simultaneous treatment

$20.399 \mu \mathrm{g} / \mathrm{ml}$. Thus, it can be inferred that the Terminalia paniculata possess high antioxidant activity at par with the standard. DNA can be damaged by most reactive free radical species like hydroxyl free radicals. Some of the dietary phytochemicals can prevent DNA damage by scavenging $\mathrm{HO} \bullet$ and $\mathrm{Fe} 2+$ ions. An antioxidant donates hydrogen to the hydroxyl free radical and makes them inactive from being involved in further reactions [21]. In the present study, the hydroxyl radical scavenging activity revealed a considerable antioxidant potential of the plant extract.

Stem bark extracts of T. arjuna were found to be rich in antioxidant compounds [20]. Similarly, the methanolic fruit extract of T. paniculata showed significant antioxidant potential. Moreover, the antioxidant activity of T. arjuna L. extracts showed variations depending upon the nature of extracting solvents as well as the nature of raw materials to be extracted.

Plants, especially fruits, vegetables, medicinal herbs, etc., have a vivid variety of free radical scavenging molecules such as phenolic acids, flavonoids, quinones, coumarins, and tannins. Furthermore, they may contain some other endogenous metabolites with high antioxidant activity $[22,23]$. Similarly, the preliminary phytochemical studies of the fruit extract of T. paniculata revealed significant occurrence of several phytochemical compounds, which are of great therapeutic value.

So many reports have been published earlier to evaluate the genotoxicity of plant extracts using $A$. сера root meristem. Several important chromosome aberrations such as $\mathrm{C}$-metaphase, vagrant chromosomes, laggards in metaphase, and anaphases were obtained. C-metaphase was found in lower concentrations of plant extracts. Plant-derived compounds are being used in anticancer studies [24]. Plant extract is the main source of potential bioactive compounds that might have generated the aberrations in Allium root tip meristem [25]. Apoptosis is an important developmental and regulated process which may occur due to the cytogenetic changes in the cell [26]. The results obtained from the present study with the modulatory action of the fruit extract of T. paniculata gave strong findings regarding their antigenotoxicity. Furthermore, it has an appreciable antioxidant potential.

\section{CONCLUSIONS}

The present study is mainly focused on the antigenotoxicity and antioxidant potential of the fruit extract of an important dye yielding plant T. paniculata Roth. From the investigation, antigenotoxicity studies revealed the protective role of the fruit extract induced by $\mathrm{H}_{2} \mathrm{O}_{2}$. The fruit extract showed a substantial modulatory effect by means of an inhibition percentage and while in the case of antioxidant activity, the fruit extract showed significant antioxidant potential.

\section{ACKNOWLEDGMENT}

The first author is thankful to the University of Calicut for providing financial support.

\section{AUTHORS' CONTRIBUTIONS}

All authors contribute equally.

\section{CONFLICTS OF INTEREST}

There are no conflicts of interest.

\section{REFERENCES}

1. Prajitha V, Thoppil JE. Induction of giant cells by the synthetic food colorants viz. lemon yellow and orange red. Cytotechnology 2016;68:443-50

2. Vazhangat P, Thoppil JE. Apoptotic induction via membrane/DNA damage and metabolic inactivation by synthetic food colorants in Allium cepa root meristem. Turk J Biol 2016;40:922-33.

3. Halliwell B, Gutteridge JM. The definition and measurement of antioxidants in biological systems. Free Radic Biol Med 1995; 18:125-6.

4. Li Y, Trush MA. Reactive oxygen-dependent DNA damage resulting from the oxidation of phenolic compounds by a copper-redox cycle mechanism. Cancer Res 1994;54:1895-8.

5. Nose K. Role of reactive oxygen species in the regulation of physiological functions. Biol Pharm Bull 2000;23:897-903.

6. Valko M, Rhodes C, Moncol J, Izakovic MM, Mazur M. Free radicals, metals and antioxidants in oxidative stress-induced cancer. Chem Biol 2006;160:1-40.

7. Celik K, Toğar B, Türkez H, Taşpinar N. In vitro cytotoxic, genotoxic, and oxidative effects of acyclic sesquiterpene farnesene. Turk J Biol 2014;38:253-9.

8. Demir E, Kaya N, Kaya B. Genotoxic effects of zinc oxide and titanium dioxide nanoparticles on root meristem cells of Allium cepa by comet assay. Turk J Biol 2014;38:31-9.

9. Sharma S, Vig AP. Antigenotoxic effects of Indian mustard Brassica juncea (L.) Czern aqueous seeds extract against mercury $(\mathrm{Hg})$ induced 
genotoxicity. Sci Res Essays 2012;7:1385-92.

10. Chang ST, Wu JH, Wang SY, Kang PL, Yang NS, Shyur LF. Antioxidant activity of extracts from Acacia confusa bark and heartwood. J Agric Food Chem 2001;49:3420-4.

11. Kunchandy E, Rao MN. Oxygen radical scavenging activity of curcumin. Int J Pharm 1990;58:237-40.

12. Kumaran A. Antioxidant and free radical scavenging activity of an aqueous extract of Coleus aromaticus. Food Chem 2006;97:109-14.

13. Valentão P, Fernandes E, Carvalho F, Andrade PB, Seabra RM, Bastos ML. Antioxidative properties of cardoon (Cynara cardunculus L.) infusion against superoxide radical, hydroxyl radical, and hypochlorous acid. J Agric Food Chem 2002;50:4989-93.

14. Fitzpatrick FA. Inflammation, carcinogenesis and cancer. Int Immunopharmacol 2001;1:1651-67.

15. Asada K. Production and scavenging of reactive oxygen species in chloroplasts and their functions. Plant Physiol 2006;141:391-6.

16. Maurich T, Pistelli L, Turchi G. Anti-clastogenic activity of two structurally related pterocarpans purified from Bituminaria bituminosa in cultured human lymphocytes. Mutat Res 2004;561:75-81.

17. Rodrigues CR, Dias JH, de Mello RN, Richter MF, Picada JN, Ferraz AB. Genotoxic and antigenotoxic properties of Baccharis trimera in mice. J Ethnopharmacol 2009;125:97-101.
18. Brown EJ, Khodr H, Hider CR, Rice-Evans CA. Structural dependence of flavonoid interactions with $\mathrm{Cu} 2+$ ions: Implications for their antioxidant properties. Biochem J 1998;330:1173-8.

19. Arnao MB, Cano A, Acosta M. The hydrophilic and lipophilic contribution to total antioxidant activity. Food Chem 2001;73:239-44.

20. Chatha SA, Hussain AI, Asad R, Majeed M, Aslam N. Bioactive components and antioxidant properties of Terminalia arjuna L. extracts. Int J Food Proc Technol 2014;5:1.

21. Walia H, Kumar S, Arora S. Comparative antioxidant analysis of hexane extracts of Terminalia chebula Retz. Prepared by maceration and sequential extraction method. J Med Plant Res 2011;5:2608-16.

22. Zheng W, Wang SY. Antioxidant activity and phenolic compounds in selected herbs. J Agric Food Chem 2001;49:5165-70.

23. Cai Y, Sun M, Corke H. Antioxidant activity of betalains from plants of the Amaranthaceae. J Agric Food Chem 2003;51:2288-94.

24. Devi SE, Thoppil JE. Cytotoxic studies and phytochemical analysis of Orthosiphon thymiflorus (Roth) Sleesen. Int J Pharm 2016;8:249-55.

25. Ravindran AE, Thoppil JE. Enigmatic induction of cytomixis in Allium cepa root meristem by Aglaia edulis Roxb. leaf extract and its phytochemical rationale. Asian J Pharm Clin Res 2020;13:168-71.

26. Rubeena M, Thoppil JE. Cytotoxic potential of Cissus quandrangularis on Allium cepa root meristem. Int J Adv Pharm Sci 2018;10:1-6. 